\title{
Analisis Dampak DPK dan Pembiayaan terhadap Produktivitas Pengelolaan Dana Sosial Pada Bank Umum Syariah
}

\author{
Analysis of the impact of third parties fund and financing on productivity of managing \\ social funds in Islamic banks
}

\section{Lisnawati}

Program Studi D4 Keuangan Syariah, Politeknik Negeri Bandung

E-mail: lisnawati.ksy16@polban.ac.id

\section{Ruhadi}

Jurusan Akuntansi, Politeknik Negeri Bandung

E-mail: ruhadi@polban.ac.id

\section{Dadang Hermawan}

Jurusan Akuntansi, Politeknik Negeri Bandung

E-mail: dadang.hermawan@polban.ac.id

\begin{abstract}
Sharia bank has a function as a tamwil and baitul mal institution. This research aims to determine the influence of third-party funds and the financing channeled towards the receipt of social funds. In addition, this research also aims to find out the productivity of sharia banking in managing social funds using the DEA method with the Malmquist Index. Purposive sampling was used to collect data in this study. Based on the results of this study found that financing has a positive influence on the receipt of social funds, but third party funds bave a negative influence on the receipt of social funds. Furthermore, based on the Malmquist Index found that 4 Syariah Banks experienced an increase in the productivity of social fund management while the other 3 Syariab Banks experienced a decrease in the productivity of social fund management, resulting from sharia banking's ability to use technology and information also the management improvements.
\end{abstract}

Keywords: productivity, third party funds, financing, social funds

\section{Pendahuluan}

Amanah Undang-undang Pasal 4 UU No. 21 tahun 2008, Bank Syariah harus menjalankan fungsinya sebagai lembaga tamwil dan baitul mal. Fungsi sosial Bank Syariah dilakukan dengan menghimpun dana social yaitu pengumpulan zakat, infaq, sedekah dan wakaf. Fungsi ini sebagai bentuk kepedulian terhadap kaum dhuafa, selain sebagai tugas dan kewajiban pemerintah. Sehingga bank syariah tidak hanya menghimpun dana pihak ketiga saha, namun dapat menghimpun dana social juga (Sholikhah, 2016).

Bank umum syariah harus berjalan dengan prinsip-prinsip syariah yang terbebas dari danadana tidak halal. Dana ini akan dipisahkan dalam laporan dana kebajikan atau qardbul hasan. Ciri khas yang menjadi pembeda antara bank konvensional dengan bank syariah dalam menjalankan fungsinya yaitu dengan melakukan penghimpunan dana-dana sosial, baik berupa zakat, infaq, sedekah maupun wakaf yang dapat berasal dari internal maupun eksternal perbankan syariah.

Tahun ke tahun dana pihak ketiga terus mengalami peningkatan yang signifikan (Apriyanthi, Purbayati, \& Setiawan, 2020) begitu pula dengan pembiayaan akan tetapi hal ini tidak berbanding 
lurus dengan dana sosial yang berhasil dihimpun oleh perbankan syariah. Dana sosial yang dihimpun dari tahun ke tahun mengalami fluktuasi, sehingga dapat diketahui bahwa perkembangan pembiayaan yang disalurkan dan dana pihak ketiga tidak berbanding lurus dengan penerimaan dana sosial.

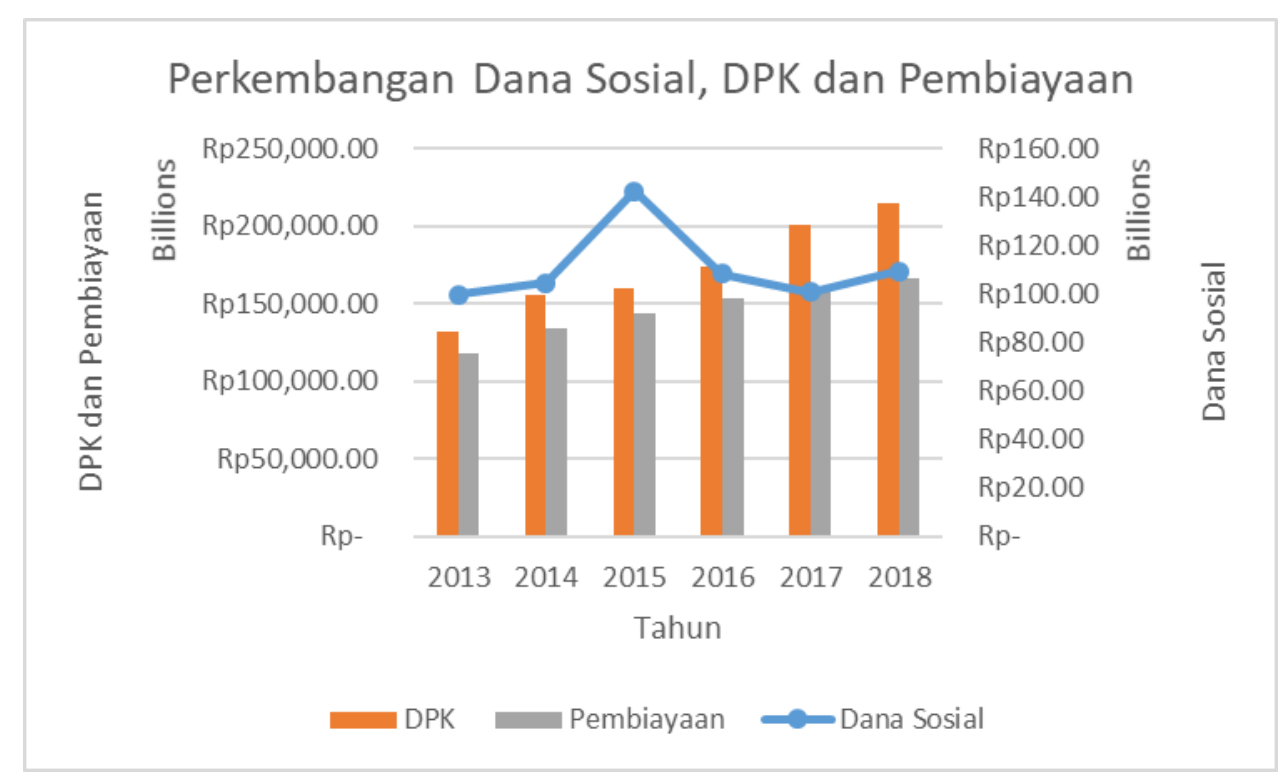

Gambar 1. Perkembangan dana sosial, DPK dan Pembiayaan

Pemanfaatan dana sosial juga harus dikelola dengan baik dan disalurkan seefektif mungkin oleh karena itu, pengukuran kinerja bagi lembaga keuangan syariah sangat diperlukan agar dapat dievaluasi manajemen perusahaan atau bank syariah tersebut. Pengukuran kinerja yang paling sering diukur yaitu pengukuran kinerja bank syariah sebagai lembaga tamwil atau lembaga bisnis, sehingga sangat penting untuk melakukan pengukuran kinerja bank syariah sebagai lembaga sosial.

\section{Kajian Pustaka}

\subsection{Dana Sosial Bank Syariah}

Perbankan syariah menghimpun dana sosial dengan melakukan pengumpulan dana zakat, infaq, sedekah dan wakaf baik yang berasal dari masyarakat maupun yang berasal dari internal perbankan syariah sendiri. Hal tersebut merupakan fungsi sosial dari perbankan syarian sebagai bentuk kepedulian terhadap kaum dhuafa (Sholikhah, 2016).

Perbankan syariah harus berjalan sesuai dengan prinsip syariah, harta harus berputar atau diniagakan sehingga tidak berpusat hanya kepada sekelompok orang saja. Menimbun harta merupakan perbuatan yang tidak disukai karena akan menyebabkan harta menjadi tidak produktif. Zakat yang dikenakan pada harta tidak produktif lebih besar dibandingkan dengan harta yang produktif (Andrianto \& Firmansyah, 2019).

\subsection{Produktivitas}

Menurut Paul Mali, produktivitas tidak sama dengan produksi, tetapi produksi, performansi kualitas, hasil tersebut merupakan komponen dari produktivitas. Maka dapat dikatakan bahwa produktivitas yaitu kombinasi dari efektivitas dan efisiensi (Rahim, 2016). produktivitas dapat digambarkan secara teknis dan finansial. Secara teknis, produktivitas merupakan pengefisiensian produksi, sedangkan secara finansial yaitu pengukuran produktivitas antara input dan output (Theresia, 2004). 
Manfaat dari pengukuran produktivitas diantaranya, perusahaan mampu untuk menilai efisiensi dari sumberdayanya, perencanaan menjadi lebih efektif dan efisien, tujuan perusahaan dapat diorganisasikan kembali dengan memberikan prioritas tertentu, perencanaan target tingkat produktivitas dimasa yang akan datang, strategi peningkatan produktivitas dapat ditetapkan berdasarkan informasi yang diperoleh dan pengukuran produktivitas dapat menciptakan tindakan yang kompetitif dalam upaya peningkatan produktivitas yang dilakuakn dengan cara terus menerus.

Pengukuran produktivitas memiliki beberapa model salah satunya yaitu Malmquist Index. Malmquist Index merupakan pendekatan fungsi untuk menggambarkan teknolodi dalam mendefinisikan indeks input, output serta produktivitas (Rahim, 2016).

\subsection{Dana Pihak Ketiga}

Sebagai media intermediasi, Bank Syariah berfungsi sebagai lembaga keuangan yang memiliki tugas untuk menghimpun dana dari masyarakat. Simpanan dan investasi merupakan kegiatan yang dilakukan oleh Bank Syariah untuk menghimpun dana (Anisa \& Tripuspitorini, 2019).

Dana pihak ketiga merupakan dana yang dititipkan oleh masyarakat kepada bank melalui perjanjian atau akad antara penyimpan dana dengan bank baik dalam bentuk tabungan, giro dan deposito menggunakan prinsip syariah, dengan rumus sebagai berikut, (Susilowati \& Nawangsasi, 2018).

$$
\text { DPK }=\text { Giro }+ \text { Deposito }+ \text { Tabungan }
$$

\section{Rumus 1. DPK}

\subsection{Pembiayaan}

Berbagai macam strategi akan dilakukan oleh Bank Syariah dalam melakukan pengumpulan dana masyarakat yang kemudian dana tersebut akan dijadikan sebagai sumber dana yang disalurkan kepada masyarakat itu kembali dalam bentuk pembiayaan yang disalurkan (Setiawan, 2018).

\section{Metode Penelitian}

\subsection{Metode, Data dan Variabel}

Metode deskriptif kuantitatif digunakan dalam penelitian ini dengan pengambilan sampel dan populasi menggunakan purposive sampling atau pemilihan populasi dan sampel dengan kriterian tertentu. Data berasal dari laporan keuangan Bank Umum Syariah yang dipublikasikan dan dapat diakses langsung pada laman Otoritas Jasa Keuangan, dengan kata lain pada penelitian ini menggunakan data sekunder.

Variable dependen merupakan variable yang dipengaruhi atau menjadi akibat karena adanya variable bebas. Sedangkan variable independen merupakan variable bebas yang mempengaruhi atau menjadi penyebab timbulnya variable dependen (Sugiyono, 2016).

Variabel dependen yang digunakan dalam penelitian ini adalah penerimaan dana sosial sedangkan variable independen yang digunakan adalah pembiayaan dan dana pihak ketiga. Lebih lanjut, penelitian ini menggunakan variable input dan output untuk dilakukan pengukuran produktivitas pengelolaan dana sosial pada Bank Umum Syariah.

\subsection{Teknik Analisis Data}

Penelitian ini menggunakan analisis data panel. Data panel merupakan penggabungan antara data cross section dan data time series. Data time series data yang dikumpulkan dari waktu ke waktu 
terhadap suatu individu sedangkan data cross section adalah data yang dikumpulkan dari waktu ke waktu terhadap banyak individu. Analisis regresi data panel merupakan alat analisis regresi dari data yang dikumpulkan secara individu (cross section) dan diikuti pada waktu tertentu (time series) (Mahulete, 2016). Analisis data panel dalam penelitian ini dilakukan dengan metode common effect, fixed effect dan random effect, sedangkan untuk menentukan metode mana yang lebih sesuai dengan penelitian ini maka digunakan Uji Chow, Uji Hausman dan Uji Lagrange Multiplier.

Menurut Gujarati dalam Kasmiarno, et.al. (2017), uji asumsi klasik tidak diperlukan dalam analisis data panel karena data panel dapat meminimalkan bias yang kemungkinan besar muncul dalam analisis, memberikan banyak informasi, variasi dan degree of freedom.

\subsection{Pengujian Hipotesis}

Uji T dilakukan untuk menguji hubungan dari regresi secara parsial, dalam uji t statistic pada dasarnya menunjukkan seberapa jauh pengaruh suatu variable penjelas secara individual dalam menerangkan variasi variable terikat. Selanjutnya, Uji f statistik yaitu menunjukkan apakah semua variabel bebas yang dimaksudkan dalam model mempunyai pengaruh secara bersama-sama terhadap variabel terikat Koefisien determinasi $\left(\mathrm{R}^{2}\right)$ mengukur tingkat ketepatan atau kecocokan dari regresi data panel, yaitu merupakan proporsi presentase sumbangan X1,X2 terhadap variasi (naik turunnya) Y (Mahulete, 2016).

DEA merupakan metodologi yang digunakan untuk mengevaluasi efisiensi dari suatu unit pengambilan keputusan yang akan bertanggung jawab menggunakan sejumlah input untuk memperoleh output yang menjadi target (Rakhmadi, 2010).

Nilai hasil dari evaluasi DEA memiliki range 1-0 dimana semakin mendekati 1 artinya semakin efisien dan sebaliknya semakin mendekati nilai 0 semakin inefisien (W. cooper William, et al, 2006).

Malmquist indeks diperkenalkan oleh Caves, Christensen dan Diewert pada tahun 1982, menurut Cooper et. al dalam Rusydiana (2018) indeks malmquist merupakan indeks bilateral yagn digunakan untuk membandingkan teknologi produksi dua unsur ekonomi. Suatu aktivitas dapat disebut efisien jika usaha yang telah dilakukan menghasilkan output yang maksimal, suatu kegiatan dapat dikatakan efisien jika dengan usaha yang minimal dapat mencapai output tertentu (Rusydiana, 2018).

\section{Hasil dan Pembahasan}

\subsection{Pemilihan Model Data}

Tabel 1. Pemilihan Model

\begin{tabular}{|l|l|}
\hline Uji & Probabilitas \\
\hline Uji Chow & 0.0000 \\
\hline Uji Hausman & 0.0003 \\
\hline
\end{tabular}

Berdasarkan hasil uji chow diketahui bahwa probabilitas $<0.05$ maka model data yang terpilih adalah model fixed effect. Selanjutnya dilakukan uji hausman untuk mengetahui model mana yang lebih sesuai antara model fixed effect dengan model random effect.

Hasil uji hausman menyatakan bahwa model yang sesuai adalah model fixed effect karena nilai probabilitas < 0.05. Uji Lagrange Multiplier tidak dilakukan karena berdasarkan dua uji diatas, model yang terpilih adalah model fixed effect. 
Uji asumsi klasik tidak dilakukan dalam hal ini karena data panel dapat meminimalkan bias yang kemungkinan muncul dalam analisis.

\subsection{Uji Hipotesis}

\subsubsection{Uji T}

Tabel 2. Uji T

\begin{tabular}{|l|l|}
\hline Variabel & Probabilitas \\
\hline Pembiayaan & 0.0033 \\
\hline DPK & 0.0106 \\
\hline
\end{tabular}

Sumber : data sekunder yang diolah, 2020 berikut :

Berikut merupakan penjelasan dari hasil pengujian regresi data panel diatas yaitu sebagai

1. Pengujian Hipotesis Pertama $\left(\mathrm{H}_{1}\right)$

Pengujian hipotesis pertama dalam penelitian ini adalah terdapat pengaruh pembiayaan terhadap Penerimaan Dana Sosial. Pada tabel diperoleh nilai signifikansi dari Pembiayaan yaitu sebesar 0,0033 yang berarti lebih kecil dari taraf signifikansi 0,05 dan mempunyai koefisien regresi sebesar 0,0018, sehingga variabel pembiayaan berpengaruh positif signifikan terhadap Penerimaan Dana Sosial. Maka secara parsial $\mathrm{H}_{1}$ diterima.

2. Pengujian Hipotesis Kedua $\left(\mathrm{H}_{2}\right)$

Pengujian hipotesis kedua dalam penelitian ini adalah terdapat pengaruh DPK terhadap Penerimaan Dana Sosial. Pada tabel diperoleh nilai signifikansi dari DPK yaitu sebesar 0,0106 yang berarti lebih kecil dari taraf signifikansi 0,05 dan mempunyai koefisien regresi sebesar 0,0011, sehingga variabel DPK berpengaruh negatif signifikan terhadap Penerimaan Dana Sosial. Maka secara parsial $\mathrm{H}_{2}$ diterima.

\subsubsection{Uji F}

Tabel 3. Uji F

\begin{tabular}{lrlr}
\hline \hline R-squared & 0.930821 & Mean dependent var & $1.59 \mathrm{E}+10$ \\
Adjusted R-squared & 0.914051 & S.D. dependent var & $2.19 \mathrm{E}+10$ \\
S.E. of regression & $6.43 \mathrm{E}+09$ & Akaike info criterion & 48.19444 \\
Sum squared resid & $1.37 \mathrm{E}+21$ & Schwarz criterion & 48.56679 \\
Log likelihood & -1003.083 & Hannan-Quinn criter. & 48.33092 \\
F-statistic & 55.50310 & Durbin-Watson stat & 2.697351 \\
Prob(F-statistic) & 0.000000 & & \\
\hline \hline
\end{tabular}

Sumber : data sekunder yang diolah, 2020

Berdasarkan table diatas menunjukkan bahwa nilai Prob(F-Statistic) sebesar 0,000. Maka, 
probabilitasnya jauh lebih kecil dari 0,05 sehingga dapat dikatakan bahwa DPK dan Pembiayaan secara bersama-sama berpengaruh signifikan terhadap Penerimaan Dana Sosial.

\subsubsection{Uji Koefisien}

Tabel 4. Uji Koefisien

\begin{tabular}{lrlr} 
R-squared & 0.930821 & Mean dependent var & $1.59 \mathrm{E}+10$ \\
Adjusted R-squared & 0.914051 & S.D. dependent var & $2.19 \mathrm{E}+10$ \\
S.E. of regression & $6.43 \mathrm{E}+09$ & Akaike info criterion & 48.19444 \\
Sum squared resid & $1.37 \mathrm{E}+21$ & Schwarz criterion & 48.56679 \\
Log likelihood & -1003.083 & Hannan-Quinn criter. & 48.33092 \\
F-statistic & 55.50310 & Durbin-Watson stat & 2.697351 \\
Prob(F-statistic) & 0.000000 & & \\
\hline \hline
\end{tabular}

Sumber : data sekunder yang diolah, 2020

Berdasarkan table dapat diketahui besarnya adjusted $\mathrm{R}$ square yaitu sebesar 0,914 atau 91,4\%. Dapat disimpulkan bahwa besar kemungkinan variabel DPK dan Pembiayaan terhadap Penerimaan Dana Sosial yang dapat diterangkan oleh model persamaan ini adalah sebesar 91,4\% dan sisanya sebesar $8,6 \%$ dijelaskan oleh variabel yang lain yang tidak terdapat dalam penelitian ini.

\subsection{Tingkat Produktivitas Dana Sosial Perbankan periode 2013-2018}

Tabel 5. Produktivitas

\begin{tabular}{|l|l|l|l|l|l|}
\hline BUS & EFFCH & TECHCH & PECH & SECH & TFPCH \\
\hline Muamalat & 1.000 & 0.560 & 1.000 & 1.000 & 0.560 \\
\hline BRI Syariah & 0.985 & 1.003 & 1.000 & 0.985 & 0.987 \\
\hline BNI Syariah & 1.000 & 1.147 & 1.000 & 1.000 & 1.147 \\
\hline Mandiri Syariah & 0.697 & 1.120 & 0.747 & 0.933 & 1.059 \\
\hline BCA Syariah & 0.884 & 1.772 & 1.000 & 0.884 & 1.566 \\
\hline Panin Syariah & 1.000 & 3.211 & 1.000 & 1.000 & 3.211 \\
\hline BJB Syariah & 1.000 & 0.026 & 1.000 & 1.000 & 0.026 \\
\hline Mean & 0.931 & 0.760 & 0.959 & 0.971 & 0.708 \\
\hline Max & 1.000 & 3.211 & 1.000 & 1.000 & 3.211 \\
\hline Min & 0.697 & 0.026 & 0.747 & 0.884 & 0.026 \\
\hline Periode Observasi & & & & & \\
\hline
\end{tabular}




\begin{tabular}{|l|l|l|l|l|l|}
\hline $2013-2014$ & 0.999 & 1.011 & 1.000 & 0.999 & 1.010 \\
\hline $2014-2015$ & 1.001 & 0.773 & 1.000 & 1.001 & 0.774 \\
\hline $2015-2016$ & 0.883 & 1.758 & 1.000 & 0.883 & 1.553 \\
\hline $2016-2017$ & 0.984 & 0.000 & 0.912 & 1.079 & 0.000 \\
\hline $2017-2018$ & 0.805 & 0.000 & 0.890 & 0.904 & 0.000 \\
\hline Mean & 0.931 & 0.760 & 0.959 & 0.971 & 0.708 \\
\hline
\end{tabular}

Sumber : data sekunder yang diolah, 2020

Secara umum bank syariah mengalami peningkatan produktivitas dalam pengelolaan dana sosialnya hal tersebut terlihat dari adanya empat bank syariah yang mengalami peningkatan antara lain Bank BNI Syariah sebesar 1.147, Bank Syariah Mandiri sebesar 1.059, Bank BCA Syariah sebesar 1.566 dan Bank Panin Syariah sebesar 3.211. Bank BJB Syariah memiliki tingkat produktivitas terendah dalam hasil penelitian ini yaitu ssebesar 0.026, angka ini sangat jauh bila dibandingkan dengan bank Syariah lainnya.

Peningkatan produktivitas pada bank umum syariah di Indonesia secara umum dipengaruhi oleh perbaikan pada aspek manajerial yang dapat dilihat dalam Pure Efficiency Change (PECH) dan kemudian ditopang oleh kemampuan bank syariah dalam pemanfaatan teknologi dan informasi (TECHCH).

\subsection{Pembiayaan berpengaruh terhadap Penerimaan Dana Sosial}

Hasil uji statistik pada tabel dapat menunjukkan bahwa Pembiayaan berpengaruh positif terhadap penerimaan dana sosial karena memiliki nilai Prob. $<0,05$ yaitu sebesar 0,0033 dan nilai pada koefisien regresi memiliki nilai yang positif. Diperolehnya hasil Pembiayaan berpengaruh positif terhadap penerimaan dana sosial maka dapat diartikan apabila bank memiliki pembiayaan yang tinggi maka kecenderungan bank untuk menerima dana sosial akan semakin tinggi. Karena saat bank Syariah memiliki pembiayaan yang tinggi besar kemungkinan bank syariah akan menerima dana zakat yang tinggi pula berdasarkan hasil dari bagi hasil yang harus dikeluarkan zakatnya atau dari denda-denda yang diterima oleh bank apabila nasabah melakukan suatu pelanggaran seperti kelalaian dalam memenuhi kewajibannya, diiringi dengan pendapatan bank syariah yang harus dikeluarkan zakatnya.

\subsection{Dana Pihak Ketiga berpengaruh terhadap Penerimaan Dana Sosial}

Hasil uji statistik pada tabel dapat menunjukkan bahwa DPK berpengaruh positif terhadap penerimaan dana sosial karena memiliki nilai Prob. $<0,05$ yaitu sebesar 0,0106 dan memiliki nilai koefisien regresi yang negatif. Artinya apabila nilai DPK tinggi maka kecenderungan bank untuk menerima dana sosial akan semakin rendah. Karena dana social yang diterima dari masyarakat akan tergantung pada kebijakan dari nasabah bank tersebut sehingga bank tidak memiliki wewenang untuk memotong atau mendebet dana pihak ketiga yang dititipkan pada bank Syariah

Hal ini tidak sesuai dengan ketentuan zakat, dimana seharusnya harta yang disimpan baik dalamm bentuk tunai, rekening bank atau bentuk lainnya serta pendapatan yang diperoleh harus dikeluarkan zakatnya yaitu sebesar 2,5\% dari saldo terakhir. Namun perbankan Syariah sesuai dengan ketentuan tidak dapat mendebet atau memotong rekening simpanan nasabah tanpa seijin nasabah, sehingga bank tidak memiliki kewenangan untuk melakukan hal tersebut.

\subsection{Produktivitas Pengelolaan Dana Sosial}


Hasil uji statistik pada tabel 5 dapat menunjukkan bahwa terdapat empat bank umum syariah yang mengalami peningkatan produktivitas dan tiga lainnya mengalami penurunan produktivitas dengan peningkatan produktivitas tertinggi dilakukan oleh Bank Panin Syariah. Tiga bank yang mengalami penurunan produktivitas diantaranya Bank Muamalat, BRI Syariah dan BJB Syariah. Ketiga bank tersebut memiliki nilai TFPCH $<1$.

Peningkatan produktivitas dipengaruhi oleh perbaikan manajemen yang dilakukan oleh perbankan dan juga didukung dengan meningkatnya pemanfaatan teknologi dan informasi oleh perbankan syariah.

Hasil penelitian ini sejalan dengan penelitian yang dilakukan oleh Pitaloka, et.al. (2018) yang menunjukan bahwa secara umum perbankan syariah mengalami peningkatan produktivitas dalam pengelolaan dana sosialnya, namun terdapat perbedaan hasil dalam penelitian yang dilakukan oleh Pitaloka, et.al. (2018) Bank Umum Syariah yang mengalami peningkatan tertinggi merupakan Bank BJB Syariah, sedangkan dalam penelitian ini Bank Syariah dengan peningkatan produktivitas adalah Bank Panin Syariah. Peningkatan produktivitas ini disebabkan oleh tingginya kemampuan Bank Panin Syariah dalam mengikuti perkembangan teknologi dan informasi, akan tetapi sebaliknya dengan Bank BJB Syariah yang mengalami penurunan dalam kemampuan mengikuti perkembangan teknologi dan informasi.

\section{Penutup}

Berdasarkan hasil temuan dalam penelitian ini dapat diketahui bahwa pembiayaan memiliki pengaruh yang positif signifikan terhadap penerimaan dana sosial, namun dana pihak ketiga memiliki pengaruh negative signifikan terhadap penerimaan dana sosial. Selain itu, ditemukan juga bahwa produktivitas pengelolaan dana sosial pada Bank Umum Syariah mengalami peningkatan yang didukung oleh kemampuan Bank Syariah dalam meningkatkan manajemen dan kemampuan Bank Syariah dalam pemanfaatan teknologi dan informasi.

Bagi Bank Umum Syariah sebaiknya melakukan negosiasi dengan para nasabah pada awal akad untuk membayarkan zakat atas titipan atau bagihasil yang didapatnya, serta mengedukasi masyarakat akan layanan jasa penghimpunan dana sosial baik zakat, infaq, sedekah dan wakaf. Penelitian ini masih terbatas pada beberapa Bank Umum Syariah, diharapkan untuk penelitian selanjutnya dapat menambah variable maupun melakukan perbandingan-perbandingan dengan lembaga keuangan lain.

\section{Daftar Pustaka}

AAOIFI. (2017). Shari'ah Standads. Manama: Dar AlMaiman.

Aisyah, S., \& Hosen, M. N. (2018). Total Factor Productivity and Efficiency Analysis on Islamic Banks in Indonesia. Jurnal Keuangan dan Perbankan.

Ali, M. (2013). Buku Saku Perbankan Syariah. Jakarta: Kementrian Agama Republik Indonesia.

Aljuhary, I. Z. (2017). Analisis Pelaksanaan Fungsi Sosial Perbankan Syariah di Indonesia tahun 2012-2016. Retrieved November 3, 2019, from http:// repository.uinjkt.ac.id/dspace

Andrianto, \& Firmansyah, A. (2019). Manajemen Bank Syariah (Implementasi Teori dan Praktek). Surabaya: Qiara Media Partner.

Anisa, L. S., \& Tripuspitorini, F. A. (2019). Analisis Pengaruh Dana Pihak Ketiga, Non Performing Finanve Murabahah, dan Inflasi terhadap Pembiayaan Murabahah pada Bank Umum Syariah di Indonesia. Jurnal Maps (Manajemen Perbankan Syariab), 3(1), 52-64.

Apriyanthi, R., Purbayati, R., \& Setiawan. (2020). Faktor-Faktor yang Mempengaruhi Pembiayaan 
Sektor Konstruksi pada Perbankan Syariah di Indonesia. ProBank: Jurnal Ekonomi dan Perbankan Vol. 5(1), 25-35.

Aziz bin Baz, S. A. (2019). Zakat. Raudhatul Muhibbi. Retrieved from https://www.raudhatulmuhibbi.org

Harahap, S. S. (2010). Akuntansi Perbankan Syariah PSAK Syariah Baru.

Kasmiarno, K. S., \& Karjadi, M. (2017). Analisis Pengaruh Indikator Ekonomi dan Kinerja Perbankan Syariah Terhadap Penyerapan Tenaga Kerja pada Perbankan Syariah di Indonesia tahun 2008-1014. Jurnal Ekonomi Syariah Teori dan Terapan.

Mahulete, U. K. (2016). Pengaruh DAU dan PAD terhadap Belanja Modal di Kabupaten/Kote Provinsi Maluku. Retrieved Januari 2, 2020, from https://eprints.umm.ac.id

Majelis Ulama Indonesia. Fatwa DSN MUI. Retrieved Agustus 28, 2019, from https://dsnmui.or.id/kategori/fatwa/download

Marifa Team. (2014). Islamic Banking \& Finance : Principles and Practices. India: Marifa Academy.

Mohd Zain, N. R., \& Engku Rabiah Adawiah, E. A. (2017). An Analysis on Islamic Social Finance For Protection and Preservation of Maqasid al-Shariah. Jurnal of Islamic Finance.

Nasution, A. Y., \& Qomaruddin. (2015). Mekanisme Pengelolaan Dana Zakat, Infaq dan Shadaqah di Bank Syariah Sebagai Implementasi Fungsi Sosial Bank (Studi Kasus di BPR Syariah Amanah Ummah). Syariakah Vol, 1.

OJK. (2017). Siaran Pers: OJK Dorong Pembiayaan Program "Social Finance". Retrieved from https://www.ojk.go.id

OJK. (2019). Buku 8 Industri Jasa Kenandan Syariah sei Literasi Kenangan Perguruan TInggi. Jakarta: Otoritas Jasa Keuangan.

Pitaloka, J. M et.al. (2018). Determinan Produktivitas Sosial Perbankan Syariah di Indonesia: Two Stage Malmquist Productivity Index. Jurnal Studi Ekonomi dan Bisnis Islam Vol. 3.

Pontoh, S. C. (2016). Tingkat Efisiensi dan Total Produktivitas Bank Umum Syariah di Indonesia Tahun 2010 - 2014 Menggunakan Pendekatan DEA dan Malmquist Index. Jurnal Ekonomi dan Bisnis Indonesia Vol. 18.

Prehantoro. (2010). Fungsi Sosial Bank Syariah. Perspektif Vol. XV.

Rahim, A. (2016). Analisis Produktivitas Bank Muamalat Indonesia (BMI) dengan Menggunakan Malmquist Indeks. Skripsi tidak dipublikasikan.

Rakhmadi, R. S. (2010). Analisis Efisiensi dan Produktivitas Perbankan Syariah. Skripsi. Retrieved from https:// repository.uinjkt.ac.id

Rizky Putra, R. et.al. (2018). Analisis Produktivitas Perbankan Syariah di Indonesia dalam Mengelola Dana Sosial. Jurnal Ekonomi Syariah Indonesia Vol. VIII.

Rizky Putra, R. et.al. (2018). Efisiensi Perbankan Syariah dalam Mengelola Dana Sosial. The 8th Research Colloquium, .

Rusydiana, A. S. (2018). Indeks Malmquist Untuk Pengukuran Efisiensi Dan Produktivitas Bank Syariah Di Indonesia . Jurnal Ekonomi dan Pembangunan Vol. 8.

Sary, F. T. (2016). Pengukuran Tingkat Efisiensi dan Tingkat Produktivitas Bank Umum Syariah (BUS) periode 2011-2015. tidak dipublikasi. Retrieved November 3, 2019, from https://repository.uinjkt.ac.id 
Setiawan. (2018). Determinan Penentu Pertumbuhan Dana Pihak Ketiga Perbankan Syariah di Indonesia. Jurnal Maps (Manajemen Perbankan Syariab) Vol. 1(2), 1-9.

Sholikhah, S. (2016). Analisis Manfaat Dana Sosial pada Program Komunitas Usaha Mikro Muamalat Berbasis Masjid (KUM3) Baitulmaal Muamalat (BMM) Jakarta Terhadap Peningkatan Usaha Anggota di Surabaya. Retrieved from http://digilib.uinsby.ac.id

Sugiyono. (2016). Metode Penelitian Kuantitatif, Kualitatif dan R\&D. Bandung: PT Alfabet.

Susilowati, E. M., \& Nawangsasi, E. (2018). Pengaruh Kinerja Keuangan Terhadap Penyaluran Pembiayaan Pada Bank Umum Syariah di Indonesia: Periode 2013-2015. ProBank: Jurnal Ekonomi dan Perbankan Vol. 3 (1).

Theresia, L. (2004). Produktivitas. Retrieved from https://www.academia.edu

W. Cooper, W., M. Siford, L., \& Tone, K. (2011). Data Envelopment Analysis: History, Models, and Interpretations. Retrieved from https://www.researchgate.net/publication/226038831

W. Cooper, W., M. Siford, L., \& Tone, K. (n.d.). Data Envelopment Analysis A Comprehensive Text with Models, Applications, References and DEA-Solver Software Second Edition. Retrieved Januari 2, 2020, from www.springer.com

Wiroso. (2011). Produk Perbankan Syariah. Jakarta: LPFE Usakti. 